\title{
STMBOLS AND ABBREVIATIONS
}

\author{
Repository Symbols
}

The original locations of documents that appear in the text and annotations are described by symbols. The guide used for American repositories has been Symbols of American Libraries, eleventh edition (Washington, D.C.: Library of Congress, 1976). Foreign repositories and collections have been assigned symbols that conform to the institutions' own usage. In some cases, however, it has been necessary to formulate acronyms. Acronyms have been created for private manuscript collections as well.

\section{Repositories}

ADSL Archives of the Department of State, Ministry of Foreign Affairs, Monrovia, Liberia

AFRC Federal Records Center, East Point, Georgia

RG ${ }_{163}$ Records of the Selective Service System

CLSU University of Southern California Library, Los Angeles

DJ-FBI Federal Bureau of Investigation, United States Department of Justice, Washington, D.C.

DLC Library of Congress, Washington, D.C.

DNA National Archives, Washington, D.C.

RG 26 Records of the United States Coast Guard

RG 28 Records of the Post Office Department

RG 32 Records of the United States Shipping Board

RG 4I Records of the Bureau of Marine Inspection and Navigation

RG 59 General records of the Department of State

RG 60 General records of the Department of Justice

RG 65 Records of the Federal Bureau of Investigation

RG 84 Records of the Foreign Service posts of the Department of State 


\section{The Marcus Garvey and UNIA Papers}

RG 85 Records of the Immigration and Naturalization Service

RG 165 Records of the War Department, General and Special staffs; Records of the Office of the Chief of Staff

IRO Island Record Office, Spanish Town, Jamaica

JA Jamaica Archives, Spanish Town

MU University of Massachusetts Library, Amherst

N New York State Library, Albany

NFRC Federal Records Center, Bayonne, New Jersey

NN New York Public Library, New York

NNC Butler Library, Columbia University

NNHR New York Supreme Court, Hall of Records, New York

NN-Sc The Schomburg Center for Research in Black Culture, New York Public Library

N-SS Office of the Secretary of State of New York, Albany

PRO Public Record Office, London

CAB Cabinet Office

CO Colonial Office

FO Foreign Office

SDNY Southern District Court of New York

WNRC Washington National Records Center, Suitland, Maryland RG i8s Records of the Panama Canal

\section{Manuscript Collection Symbols}

$\begin{array}{ll}\text { AAG } & \begin{array}{l}\text { Amy Ashwood Garvey Papers, Lionel Yard Collection, New } \\ \text { York }\end{array} \\ \text { JEB } & \text { John E. Bruce Papers, NN-Sc } \\ \text { LC } & \text { Lusk Committee Papers, } N \\ \text { NAACP } & \text { National Association for the Advancement of Colored People } \\ & \text { Papers, DLC } \\ \text { NCF } & \text { National Civic Federation Papers, NN } \\ \text { TAM } & \text { Thaddeus A. McCormack Papers, St. Elizabeth, Jamaica } \\ \text { W } & \text { World Collection, NNC } \\ \text { WEBDB } & \text { W. E. B. Du Bois Papers, } M U\end{array}$




\section{SYmbols and Abbrevitions}

\section{Descriptive Symbols}

The following symbols are used to describe the character of the original documents:

$\begin{array}{ll}\text { ADS } & \text { Autograph document signed } \\ \text { ALS } & \text { Autograph letter signed } \\ \text { AMS } & \text { Autograph manuscript } \\ \text { AMSS } & \text { Autograph manuscript signed } \\ \text { AN } & \text { Autograph note } \\ \text { ANI } & \text { Autograph note initialed } \\ \text { D } & \text { Document } \\ \text { DS } & \text { Document signed } \\ \text { L } & \text { Letter } \\ \text { LS } & \text { Letter signed } \\ \text { MS } & \text { Manuscript } \\ \text { N } & \text { Note } \\ \text { TD } & \text { Typed document } \\ \text { TDS } & \text { Typed document signed } \\ \text { TG } & \text { Telegram } \\ \text { TL } & \text { Typed letter } \\ \text { TLI } & \text { Typed letter initialed } \\ \text { TLR } & \text { Typed letter representation } \\ \text { TLS } & \text { Typed letter signed } \\ \text { TMS } & \text { Typed manuscript } \\ \text { TN } & \text { Typed note } \\ \text { TNI } & \text { Typed note initialed } \\ \text { TNS } & \text { Typed note signed } \\ \end{array}$

\section{Published Works Cited}

ATOR African Times and Orient Review

$B F Q \quad$ Bartlett's Familiar Quotations, fifteenth edition

BM Black Man 
The Marcus Garvey and UNIA Papers

$\begin{array}{ll}C B D & \text { Chambers's Biographical Dictionary } \\ C D & \text { Chicago Defender } \\ D A B & \text { Dictionary of American Biography } \\ D A H B & \text { Dictionary of African Historical Biography } \\ D G & \text { Daily Gleaner } \\ D N B & \text { Dictionary of National Biography } \\ E A & \text { Encyclopedia Americana } \\ E B & \text { Encyclopaedia Britannica } \\ E W H & \text { Encyclopedia of World History } \\ H J & \text { Handbook of Jamaica } \\ N N H & \text { Journal of Negro History } \\ N C A B & \text { National Cyclopedia of American Biography } \\ N W & \text { Negro World } \\ N Y B & \text { Negro } \text { Year Book } \\ N Y T & \text { New York Times } \\ P P & \text { Parliamentary Papers } \\ W B D & \text { Webster's Biographical Dictionary } \\ W W C A & \text { Who's Who of Colored America } \\ W W C R & \text { Who's Who of the Colored Race } \\ W W J & \text { Who's Who in Jamaica } \\ W W W & \text { Who Was Who } \\ W W W A & \text { Who Was Who in America }\end{array}$

\section{Other Symbols and Abbreviations}

Included are abbreviations that are used generally throughout annotations of the text. Standard abbreviations, such as those for titles and scholastic degrees, are omitted. Abbreviations that are specific to a single annotation appear in parentheses after the initial citation and are used thereafter in the rest of the annotation.

ABB African Blood Brotherhood

ACL African Communities' League

AFL American Federation of Labor

AME African Methodist Episcopal church

AMEZ African Methodist Episcopal Zion church 
SYMBOLS AND ABBREVIATIONS

BSL Black Star Line, Incorporated

BWI British West Indies

CSO Colonial secretary's office

GPO Government Printing Office

IWW Industrial Workers of the World

MID Military Intelligence Division

MP Minute paper

NAACP National Association for the Advancement of Colored People

OBE Order of the British Empire

RG Record group

UNIA Universal Negro Improvement Association

USSB United States Shipping Board

\section{Monetary Symbols}

d. English pence

s. , 1- English shilling

$£ \quad$ English pound 
